\title{
網式消波材の開発と 高波・津波対策としての効果 IMPROVEMENT OF NET-TYPE WAVE ENERGY DISIPATING UNIT AND ITS APPLICABILITY TO MITIGATION OF ACCIDENTAL WAVE AND TSUNAMI HAZARD
}

\author{
平石哲也 1 黒田美里 2 ・土橋和敬 2 \\ Tetsuya HIRAISHI, Misato KURODA and Kazunori TSUCHIHASHI \\ 1正会員 博（工） 京都大学防災研究所（一 $612-8235$ 京都市伏見区横大路下三栖東ノ口 京都大学防 \\ 災研究所附属宇治川オープンラボラトリー) \\ 2 前田工繊株式会社＼cjkstart水環境保全推進部（テ919-0422 福井県坂井市春江町沖布目38-3）
}

\begin{abstract}
A net-type unit which composes about $30 \mathrm{~cm}$ rubbles in it is developed. The unit is intended to reduce the wave energy and tsunami pressure generated in accidental condition beyond the design. The rubble layer overlapped in the polyester nets can reduce the impulsive forces due to the huge wave and tsunami. Several stability coefficients have to be revealed to make a design of seawalls and breakwaters. A water channel experiment is carried out to estimate the stability coefficients using the scaled unit model of 1/50 related with 6 and 8ton in prototype. The stability in tsunami flows is moreover investigated in order to obtain the other stability function determining the applicability of the unit as counterweights.
\end{abstract}

Key Words : Accidental wave, net type wave dissipating instrument, stability in tsunami, KD number, Isbash coefficient

\section{1. はじめに}

2011年3月11日の東北太平洋沖地震による津波では多 くの海岸堤防が破堤している，その原因として，津波波 力による胸壁の破壊，引き波時の局所的な流圧力による 堤体破壊等が指摘されている. これらの要素に加えて, 堤体前面の法先洗堀による構造物の安定性低下も大きな 要素となっている. 近年, 河川堤防の法先洗堀防止工と して網状のネットに200～500 kg砕石を詰め，袋状にした 柔軟性を有する網式（あみしき）材が用いられるように なっている，ただし，網を成型し，吊り下げることがで きるように4 $\mathrm{t}$ 型までが製作され，一部の河川堤で用いら れているだけである。下迫ほがは2つの絞り口を有する 比較的剛性の強い網式消波ユニットの基礎マウンド上で の安定性を調べているが，消波材としての安定性は検討 していない. 本研究では，この網式材を海岸および港湾 構造物の消波ならびに法先洗掘防止工（網式消波材）と して活用するために，大型の6tおよび8tに相当する実機 の試験製作ならびに而久性試験を実施し，洗掘に強い海 岸堤防および防波堤の消波被覆工の開発を目的とした。
また今回の津波による被害を受け，津波規模をレベル 1およびレベル2の2段階に分けて海岸と港湾を防御する ことが提案されている.レベル1津波は，設計対象とな る歴史上繰り返された津波であり，これに対しては護岸 と防波堤は十分安定でなければならない。レベル2津波 は，将来想定される最大規模の津波であり，防波堤や護 岸だけでは防御できず，総合的な警報・避難システムの 確立が目指されている.ただし, 防波堤と護岸は倒壊し てしまわないように‘粘り強い’ 構造を持つことが要求 されるので, 堤体工法に砂礫層によるマウンド（カウン ターウェイト）を構築し，その抵抗で堤体の滑動やわず かな転倒を許すが，大きな転倒や倒壊を防ぐ．この時越 流した津波によって砕石層が動かされないように十分安 全な被覆層を必要としており，本網式消波材の活用が期 待できる. そこで，津波流作用下での安定係数を求め， 設計ができるようにした.

\section{2. 網式消波材の開発}

ポリエステル製の網材の形状を写真-1に示す.これは 


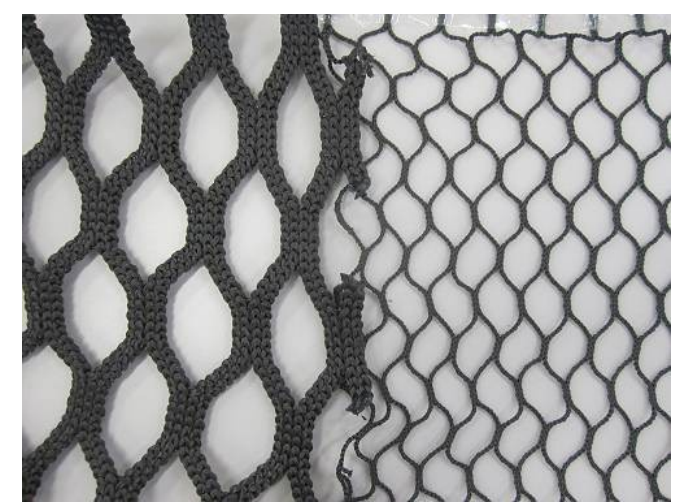

写真-1 網材の状況

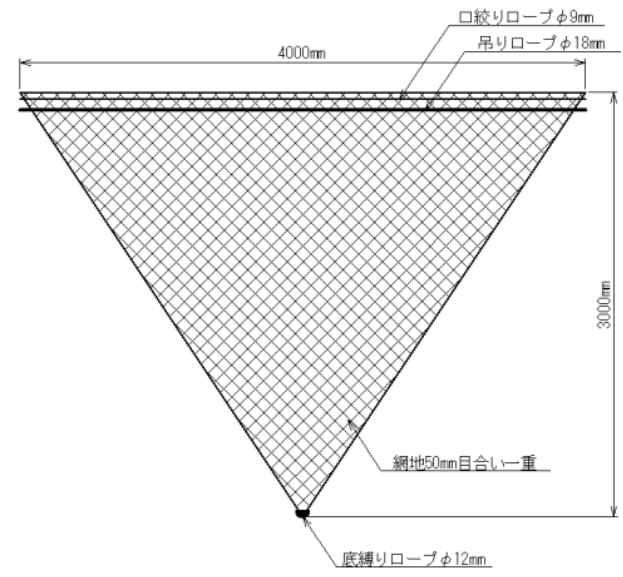

図-1８t型網式消波材の形状図

右側の細い網地が従来河川で使われている2トン型の網 材である. 左側が今回開発した網材である。網材の特徵 は工場内で袋状に編まれて，ひとつの開口部しか持たず, 現場で砕石を袋内に入れると1か所を縛るだけでユニッ トが完成でき短時間で施工できることである. 図-1に8 トン型の網式消波材の袋体の形状図を示寸．なお，6卜 ンおよび8トンは砕石を充填した時のユニットの総重量 を表す。

現地試験では，以下の項目について確認を行った。

(a) 網式消波材 6 トン(6t と記述)用および 8 トン(8t と記 述)用の施工時の円形フレイムの施工性

(b) 消波材の袋部分の結束方法と製作時間

中詰め材としては割栗砕石（150〜200 mm）を用いる.

写真-2 に製作過程を示寸. また，結束後の吊り上げ 時において，袋形状を確認し，以下の結論を得た。

6t タイプについて，中詰め材を充填後にしっかり口 が閉まることを確認できた。 また，4回転置後の網地の 状態を確認したところ, 毛羽立ちはあるものの破断しな いことが確認できた． $8 \mathrm{t}$ タイプについても，規程の網 地内に充填できることが確認でき, 4 回転置後の網地の 状態を確認したところ，1 回目に製作した 8t タイプに ついては毛羽立ちがあるものの破断個所はなかった. 写 真-3 に $8 \mathrm{t}$ タイプの転置後の写真を示す. 2 回目に製作 した $8 \mathrm{t}$ タイプについては 4 回転置後に 1 箇所破断して いた.さらに 4 回転置後（全 8 回転置後）に網地を確認
したところ，追加の破断は見受けられなかった．しかし， 中詰め材の鋭利な角により破断しそうな箇所が 1 箇所 あった. 寸なわち，波浪の作用によって激しく動く場合 は 1 部破断する可能性はあるものの, その数は 1 力所の みで全体への影響は小さいと思われる.

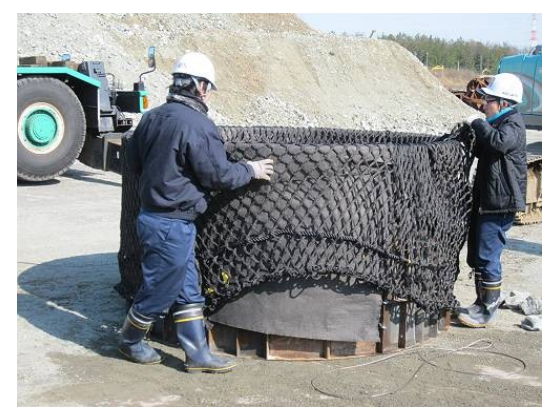

（1）円形型枠に網をかぶせる

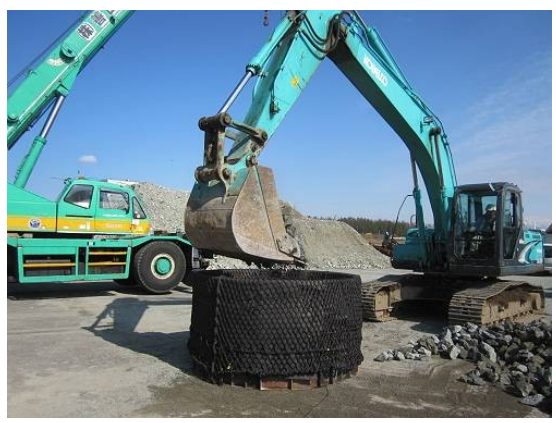

（2）砕石の投入

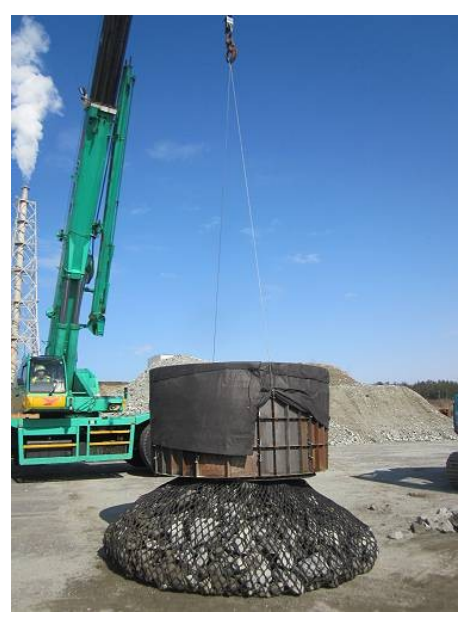

(3) 円形枠の抜き取り

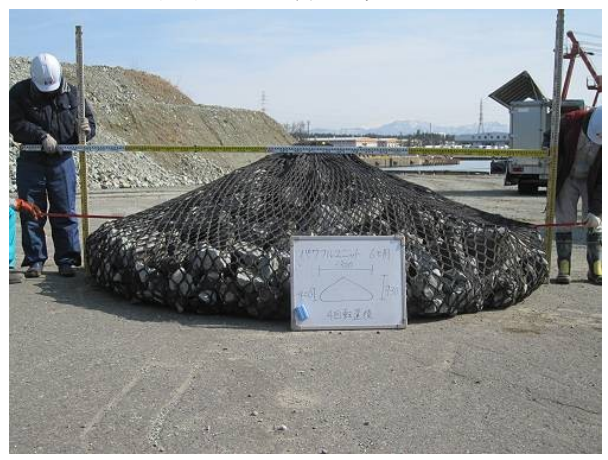

（4）網式消波材の成型

写真-2 網式消波材の試験製作 


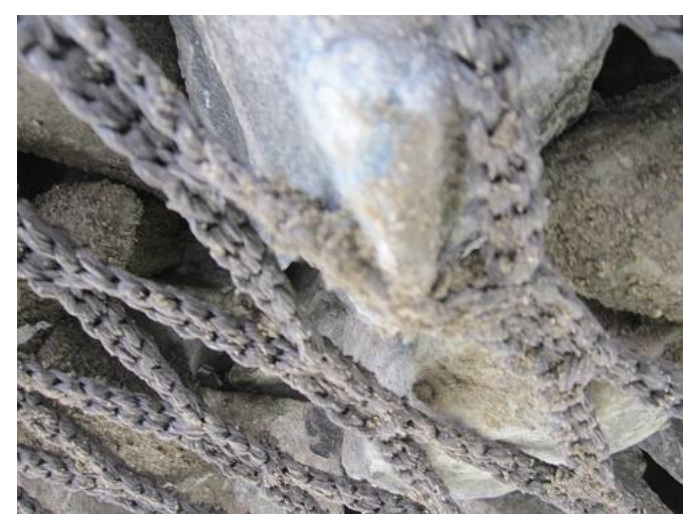

写真-3 網式消波材の破損個所

製作に要した時間は，作業員 2 名で以下のとおりであ り，現場で 10 分程度で製作が可能であることが判る.

・ $6 \mathrm{t}$ タイプ

(1) 網地セット 約 2 分 20 秒

(2) 中詰材投入約 4 分 20 秒

(3) 地切り 約 1 分 40 秒

(4) 口絞り 約 2 分 30 秒

(5) 脱型約 1 分 20 秒

計 約 12 分

・ $8 \mathrm{t}$ タイプ

\begin{tabular}{ll} 
(1) 網地セット & 約 2 分 00 秒 \\
(2) 中詰め材投入 & 約 4 分 10 秒 \\
(3) 地切り & 約 1 分 10 秒 \\
(4) 口絞り & 約 3 分 00 秒 \\
(5) 脱型 & 約 1 分 20 秒 \\
\hline 計 & 約 12 分
\end{tabular}

\section{3. 消波材としての安定性}

\section{（1）実験の方法}

波力を受ける構造物の所要質量は, 次式で示される Ns 值によるハドソン式を用いて算出することができる. (土木学会) ${ }^{2)}$

$$
M=\frac{\rho_{r} H^{3}}{N_{s}^{3}\left(S_{r}-1\right)^{3}}
$$

ここに,

$M \quad$ : 構造物の所要質量 $(\mathrm{t})$

$\rho_{r} \quad:$ 構造物の密度 $\left(\mathrm{t} / \mathrm{m}^{3}\right)$

$H$ : 安定計算に用いる波高 $(\mathrm{m})$

Ns : 安定定数. 主として被覆材の形状, 勾配, 被災率等によって決まる.

Sr : 構造物の水に対する比重（砕石は2.6） 今回は水理模型実験により，網式消波材の偶発波浪（平 石ほか） 3) や津波に対して安定な質量（所要質量）を求 めるために必要な $K_{D}$ 值を算出する.
実験施設は，長さ $50 \mathrm{~m}$ ，幅 $1 \mathrm{~m}$ ，深さ $1.5 \mathrm{~m}$ の 2 次元 造波水路を用いる.ただし，今回の実験では模型の縮尺 や設備の造波能力を考慮し, 実験対象部分を幅 $50 \mathrm{~cm}$ に 縮小して実験を行う。6t および $8 \mathrm{t}$ タイプの 2 種類の袋 体を用いる．模型縮尺は $1 / 50$ とし，下記にそれぞれの タイプの現地での模型規格を示す. 模型では 99 個の模 型を用いて消波層を製作した. それぞれの模型空中質量 は，48 および 64g である. 例として表-1に $8 \mathrm{t}$ タイプ の模型規格を示す.

図-2 は左側から偶発波浪や津波が来襲すると想定し て設置した実験模型として用いる護岸断面である.

表-1 $8 \mathrm{t}$ タイプ規格

\begin{tabular}{|c|c|c|c|c|}
\hline & 質量 & 体積 & $\begin{array}{c}\text { 出来高直 } \\
\text { 径 } D\end{array}$ & $\begin{array}{c}\text { 出来高高 } \\
\text { さ } \mathrm{H}\end{array}$ \\
\hline 実物大規格 & $8 \mathrm{t}$ & $5 \mathrm{~m}^{3}$ & $3 \mathrm{~m}$ & $0.7 \mathrm{~m}$ \\
\hline $\begin{array}{c}1 / 50 \text { 模型規 } \\
\text { 格 }\end{array}$ & $64 \mathrm{~g}$ & $40 \mathrm{~cm}^{3}$ & $6 \mathrm{~cm}$ & $1.4 \mathrm{~cm}$ \\
\hline
\end{tabular}

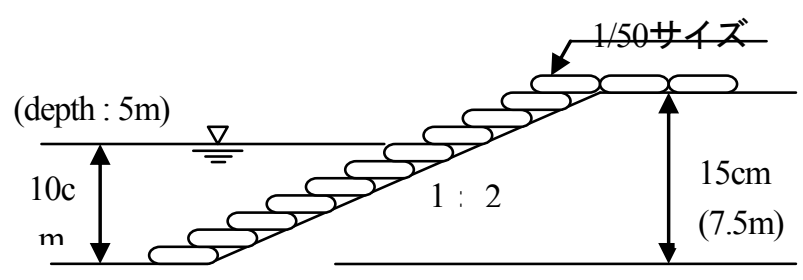

図-2 実験イメージ

作用波は不規則波とし，1000 波以上造波して元の位 置から動いたものを被災と夕なす。周期は 4 種類程度, 波高は随時変化させる. なお, 計測では, 元の位置から 移動したり滑落したものを 1.0 個と数え, 位置を変えず にその場で回転しただけのものを 0.5 個と数えた.

許容被災率（波で移動した構造物の個数の全体個数 に対する割合） $2 \%$ とし，実験により被災率 $2 \%$ になる 条件（質量 $M$, 波高 $H$ ) を求めた。模型水路では，入 力信号通りの波形が必ずしも再現できないので，あらか じめ模型のない状態で波高解析を行い，造波信号と造波 波高及び周期の関係を求めている. 以下の記述では，実 際に造波された波の波高・周期を用いて結果を示した. 水理模型実験によって求められた被災率 $2 \%$ となる質 量 $M$ および波高 $H$ から $N S$ 值を算出する. 次式は Ns 值 と $K_{D}$ 值の関係を表した式である. $K_{D}$ 值はハドソン式に おける斜面上の安定係数であり，護岸上の消波工の安定 係数として通常用いられるものであり，NS 值と以下の 関係にある。

$$
N_{s}^{3}=K_{D} \cot \alpha
$$

ここに

$\alpha \quad$ : 斜面が水平面とな寸角 $\left(^{\circ}\right)$ 
$K_{D}$ : 主として構造物の形状および被災率等に よって決まる定数

式(1)に式(2)を代入すると式(3)となる.

$$
M=\frac{\rho_{r} H^{3}}{K_{D}\left(S_{r}-1\right)^{3} \cot \alpha}
$$

式(3)に実験により求められた質量 $M$ および波高 $H$ を 入力し， $K_{D}$ 值を以下のように算出する.

$$
K_{D}=\frac{\rho_{r} H^{3}}{M\left(S_{r}-1\right)^{3} \cot \alpha}
$$

写真-4に実験模型の設置状況を示す.

\section{（2）実験の結果}

使用模型は，タイプ $6 \mathrm{t}, 8 \mathrm{t}$ 型であり，水槽水深： $88 \mathrm{~cm}$, 模型天端高 : $93 \mathrm{~cm}$ した. 模型床高は水路床より $78 \mathrm{~cm}$ である. 水路幅 : $100 \mathrm{~cm}$ より徐々に縮流させる. 対象模型幅は $50 \mathrm{~cm}$ 護岸前面の勾配は $1 / 2$ にしている. 模型設置位置前面波高は模型を設置しない状態であらか じめ解析をした值を用いる，模型実験では，水路の両端 は水路壁面との間に波消しブロック $20 \mathrm{t}$ 型および $15 \mathrm{t}$ 砕 石（現地換算）を積んで緩衝材とした。実験で用いた波 高および周期をまとめる（＜wide>）が現地換算値）；

実験ケース

1）対象周期 $T 1 / 3=1.0(7.1) \mathrm{s}, \quad 1.2(8.5) \mathrm{s}, \quad 1.4(9.9) \mathrm{s}$, $1.6(11.3) \mathrm{s}, \quad 1.8(12.7) \mathrm{s}, \quad 2.0(14.14) \mathrm{s}$

2）波高レベル：7〜12cm（3.5m）～（6m）

3）被災個数

移動個数を被災とみなし $N r$ は 20 分間で取得した。 (時化のピーク継続時間は 2 時間とされている)

\section{4）実験の配置}

各網式消波材ユニットは 99 個を使用した. 天端に 3 個の網式消波材ユニットが設置できるように砕石

(2cm) でマウンドを製作し，膜体ブロックは $6 \mathrm{t}$ 型およ び $8 \mathrm{t}$ 型を同時に設置し，同一波を使用した．網式消波 材及び緩衝材用ブロックはすべて 2 層積みとした。 網式 消波材ユニットの幅は 5 列で，千鳥に配置している．な お，本実験の最大周期は $2 \mathrm{~s}$ (現地 14.1s), 波高 $8.4 \mathrm{~cm}$ (4.2m) であり，被災率も最大となる，写真の右図は， 模型断面を示し, ガラス面との摩擦による影響を避ける ために，壁面と網式消波材ユニット模型の間に緩衝材と して波消しブロックを設置している.

網式消波材ユニットの模型は 99 個用いているので, 観測された移動個数が被災率と等しい. 計測結果を表-2 に示寸. 表中の $T 1 / 3$ は作用波の有義波周期で現地換算值 である. 実験では，模型のない状態で測定した実験水路 内の模型設置位置での波高測定結果を用い，周期につい ては入力值と測定值は一致していたので修正はしていな い. 実験では 20 分間 2 種類の波群を造波して，それぞ れについて 2 回の平均值を代表値とした.

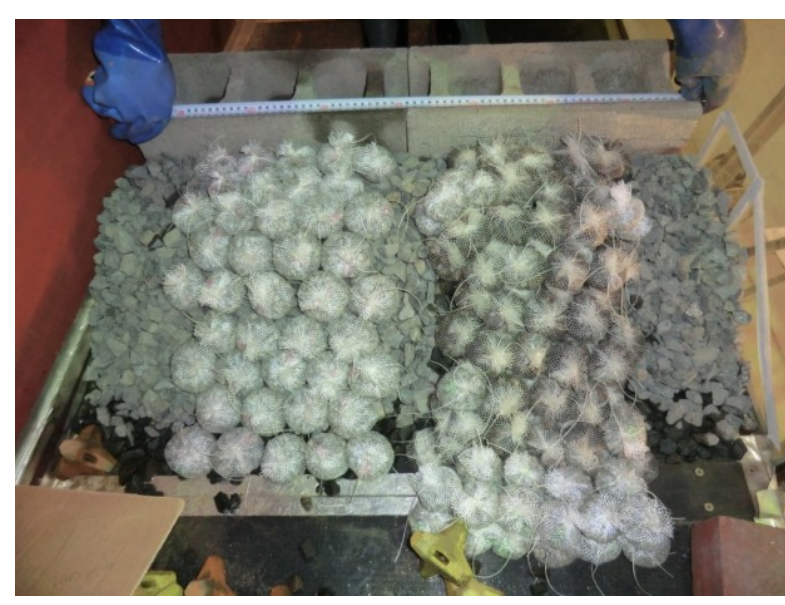

写真-4 網式消波材模型の設置 (左側 $8 \mathrm{t}$ 型，右側 $6 \mathrm{t}$ 型. 天端 3 列で 2 層積み).

表-2 $K_{D}$ 值の評価に用いる被災率

\begin{tabular}{|l|l|l|l|l|l|l|l|}
\hline $\begin{array}{l}\mathrm{T} 1 / 3 \\
\text { 現地 } \\
\text { (s) }\end{array}$ & 7.1 & 8.5 & 9.9 & 11.3 & 12.8 & 14 & $*$ \\
\hline $6 \mathrm{t}$ & $1 \%$ & $\bigcirc$ & $\bigcirc$ & $10 \%$ & $1 \%$ & $5 \%$ & 5 \\
\hline $8 \mathrm{t}$ & $\bigcirc$ & $\bigcirc$ & $\bigcirc$ & $9 \%$ & $7 \%$ & $3 \%$ & 6 \\
\hline
\end{tabular}

(ㅇ：全く動かない

* : 周期 10s 以上の偶発波浪についての平均值

実験結果から，それぞれの周期で被災率が $2 \%$ となる 波高レベルを逆算して, 安定係数を求めた. 周期 $2 \mathrm{~s} の$ 場合，計算例は以下のようになる。

$$
K_{D}=\frac{2.6 \times 4.5^{3}}{8(2.6-1)^{3}(2)}=4
$$

ただし，実験で求めた安定係数は 2 次元で観察した場合 であり，波向や積み方にもよっても差が出ると考えられ る. また, 転がって飛んでいったものはない，一般に長 周期の波にブロックは弱いが，本実験で対象とした繊維 索を用いて砕石を活用した網式消波材の安定度は，ユ ニットが動いても落ちずに斜面上にとどまっているので, より高いものとなる. 多少の変形を許容するならば,

Resiliency（粘り強さ）が発揮できる構造物になり得る.

\section{4. 津波に対する安定性}

津波に対する $K D$ 值の評価は難しく，作用する波が流 れのようになるので, 適切な数值による安定性の指標は 得られていない，ここでは，孤立波を実験水路内で作用 させて，おおよそ被災率が $2 \%$ となる津波遡上高を安定 性指標とした。

\section{（1）実験ケース}

実験に用いた孤立波（津波を模擬した正だけの水位上 昇を有する単一波）は，1/50 の縮尺模型で 3.5 4m で あり，護岸本体は越流する，ただし，本網式消波材は洗 
掘防止用として開発されているので, 越流してもその場 で動かなければ洗掘防止工として活用できる.

実験では 3 回以上の同一津波を作用させて, 計測值 のばらつきが 1 個以内であることを確認して平均值を代 表值とした. 写真-5 に実験後の状況を示寸.

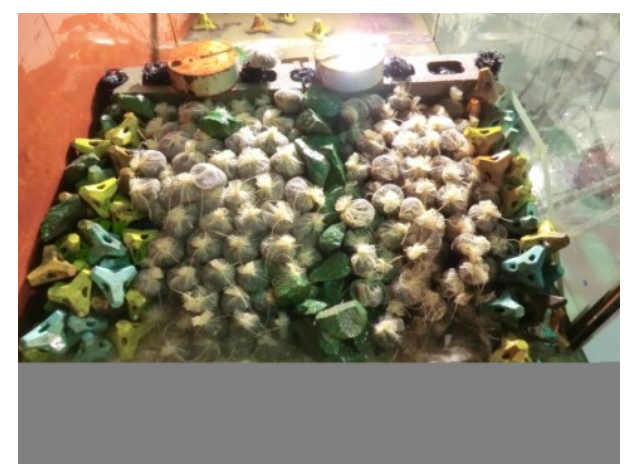

写真-5 実験室内での最大津波による移動状況 （堤体への乗り上げが一部見える）

\section{（2）実験結果}

図-3 に津波波高（遡上高（陸表面を基準とした高 さ）と被災率の関係を示す。ユニットの形状による被 災率の変化はなく, 津波高が $4 \mathrm{~m}$ になると被災率が急激 に大きくなり, 護岸としての機能が失われる可能性が高 くなる. 本堤体の条件では，3m の津波高に対して被災 率が $2 \%$ 以下となり, 現地において汀線での津波高が $3 \mathrm{~m}$ 以下であれば十分な安定性を有していることが分 かった.

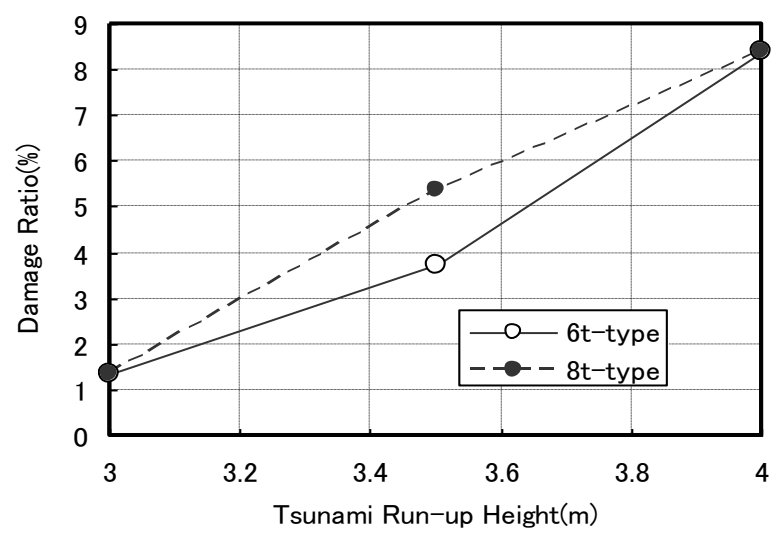

図-3 津波高と被災率の関係

\section{5. イスバッシュ定数の推定に関する模型実験}

使用水槽は，これまでの安定性実験と同一の長水路 である. 作用波は孤立波を用いて，孤立波の頂点の高さ を津波高とした. 本実験では, 護岸を越流した津波流が 陸地側の背後のカウンターウェイト層に作用して浸食を
起こす現象を防ぐために，表層を保護できる網式消波材 の安定状況を調べた. 強い流れの中での砂砂材などの安 定はイスバッシュ数によって表され，津波流速に対応し て安定性を有する網式消波材の重量が決定される.

イスバッシュ数に対しては, 岩崎ら ${ }^{4)}$ の測定結果が あり，これまでは岩崎ら ${ }^{4)}$ の実験で用いられた定数のみ が採用されているが，津波は衝撃的に作用して，流速の 変化も大きいので最大流速に相当するイスバッシュ定数 $y$ を新たに考察しておく必要がある.

\section{（1）実験方法}

測定は津波流速、津波波形，網式消波ユニットの動 摇を観測することから, 被災率 $1 \%$ に相当する流速(津 波波高)を逆算して，イスバッシュ定数 $y$ を求めた. 実 験の. 水深は $30 \mathrm{~cm}$, マウンド高は $10 \mathrm{~cm}$ し, 試験ユ ニット高は $10 \mathrm{~cm}$ を目標として 2 段の整積みを行った. 流速測定水深は $20 \mathrm{~cm}$ とした. 実験では水路内の最大流 速は $50 \sim 60 \mathrm{~cm} / \mathrm{s}$ が再現できる. 写真-6 は津波作用前の 整積み状態を示す．図-4 は実験イメージである.

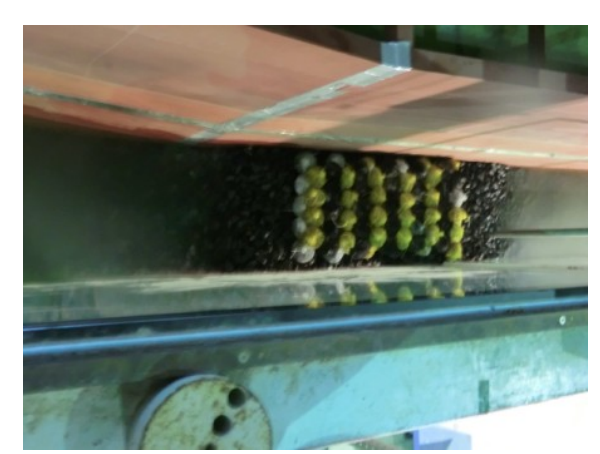

写真-6 網式消波部材(8 トンタイプ)の整積み

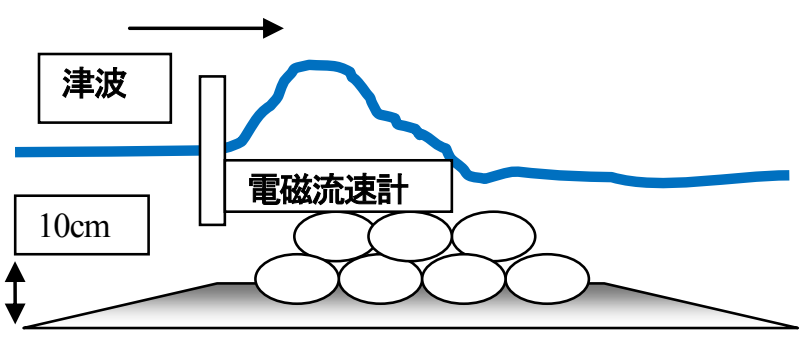

図-4 津波流中の網式消波材の安定性実験イメージ

\section{（2）実験の結果}

造波装置に与える津波信号入力值 Input（孤立波の波 高值）を変化させて上層移動個数（下層最後端の移動は 無視）を数えたところ，移動限界（1\%～2\%）は、造波 機に与える津波信号 Input $(\mathrm{cm})$ で 7.2 7.8 程度の時に相 当した.

図-5 は Input 值が 7.2 のときの測定津波流速 $U o(\mathrm{~cm} / \mathrm{s})$ の波形の例を, 図-6 に津波高(入力值)に対寸る移動個数 を示す. 津浪高と最大津波流速は，あらかじめ模型ユ ニットを設置しない時に相関を測っており，図-7 のよ 


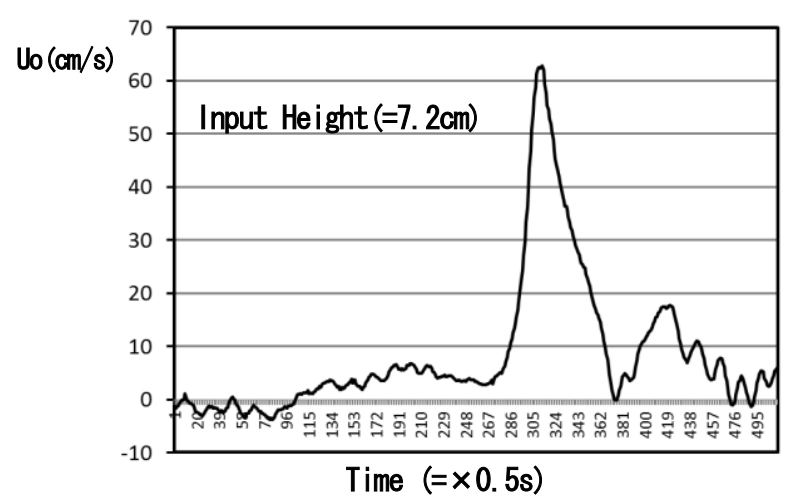

図-5 津波流速波形の例

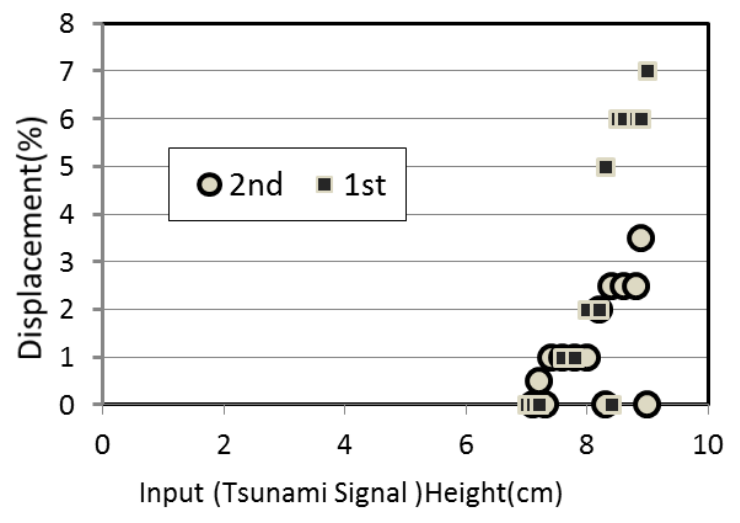

図-6＼cjkstart津波高と被災率（Displacement）の相関

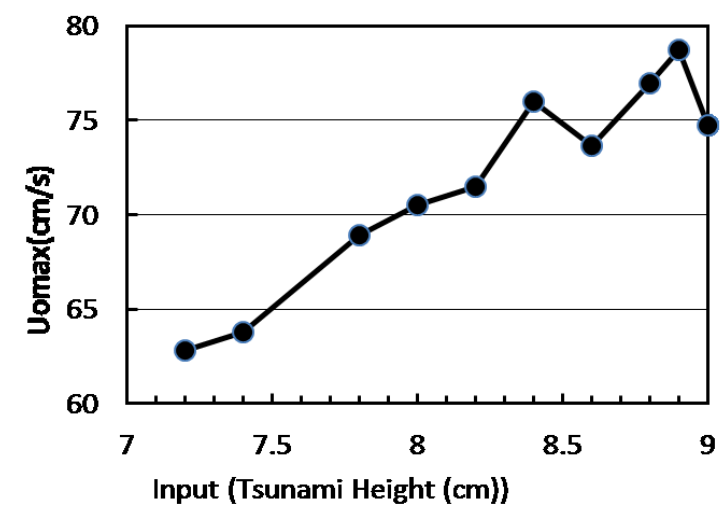

図-7 作用流速 $(\mathrm{cm} / \mathrm{s})$ (縦軸) と津波高入力值(横軸)の関係

うになる。これは網式消波材の無い状態で測定した最大 流速の変化である，図から示されるように，限界流速は $63 \mathrm{~cm} / \mathrm{s}$ から $68 \mathrm{~cm} / \mathrm{s}$ と読み取ることができる.

イスバッシュ定数 $y$ の計算は次式で行った.

$$
W=\frac{\pi w U_{o}^{6}}{48 y^{6} g^{3}\left(w / w_{o}-1\right)^{3}(\cos \theta-\sin \theta)^{3}}
$$

$$
\begin{array}{ll}
\text { ここで, } & \\
\text { ユニット重量 } & W=8000 \mathrm{~kg} \\
\text { 津波流速 } & U_{0}=4.45 \mathrm{~m} / \mathrm{s} \sim 4.81 \mathrm{~m} / \mathrm{s} \\
\text { ユニットの単位体積重量 } & \quad w=2.6 \mathrm{t} / \mathrm{m} 3 \\
\text { 水の単位体積重量 } & w_{0}=1.0 \mathrm{t} / \mathrm{m}^{3} \\
\text { マウントド勾配 } & \theta=0
\end{array}
$$

である

以上を用いると，イスバッシュ数定数 $y$ の計算結果は 大よそ， $y=0.592 \sim 0.639$ となる. この值は，岩崎ほか 5 が定常流速で行った実験值 0.9 に比べて小さいが，非定 常の津波流速を与えているので，その影響が現れ，津波 流に関するイスバッシュ数 $y$ は約 0.6 程度で表されるも のと考えられる.

\section{6. まとめ}

本実験において $6 \mathrm{t}$ およ゙ $8 \mathrm{t}$ 型の網式消波材の而波安 定性と津波安定性について検討を行った. その結果, 以 下のことが判明した；

1）網式消波材は被覆ブロックとして柔軟性を有して おり，変形しても移動する割合が少ない。

2）安定係数 $K_{D}$ で而波安定性を評価すると $6 \mathrm{t}$ および $8 \mathrm{t}$ で，それぞれ約 $K D=5$ および 6 が得られた.

3）津波に対しては, 遡上高 $3 \mathrm{~m}$ の津波までは十分な 安定性を有寸る.

4）津波流に対するイスバッシュ定数 $y$ は 0.6 程度にな る.

なお，本実験結果は限られたケースでの検討であり， 現地における適用に当たっては, マウンド材の条件, 設 置場所の地形，施工性等に留意する必要があり, 諸条件 を変更した実験等も必要である.

\section{参考文献}

1）下迫健一郎, 久保田真一, 松本朗, 半沢稔, 篠村幸 廣, 尾池宣佳, 池谷毅, 秋山真吾袋型根固め材を用 いた混成堤マウンド被覆材の而波安定性と耐久性港 湾空港技術研究所報告Vol.43, No.1, pp.49-83, 2003.

2) 土木学会 : 海岸施設設計便覧, 土木学会, pp.301-309, 2000.

3）平石哲也 - 平山克也 - 加島寛章 - 春男和人 - 宮里一 郎：偶発波浪荷重による被害例とその特性，海岸工 学論文集, Vol.55, pp.981-985, 2008.

4) 岩崎敏夫 - 真野明 - 中村武弘・堀越伸幸 : 潜堤定マ ウンド材およびプレパックド堤に作用する定常流流 体力に関する実験的研究，海岸工学論文集，Vol.31, pp.527-531, 1984.

(2012.9.30受付) 